\title{
Dossier 4 : La ville et l'enjeu du développement durable
}

Helga-Jane Scarwell, Richard Laganier et Marc Kaszynski

\section{(2) OpenEdition \\ 1 Journals}

Édition électronique

URL : http://journals.openedition.org/developpementdurable/662

DOI : 10.4000/developpementdurable.662

ISSN : 1772-9971

\section{Éditeur}

Association DD\&T

\section{Référence électronique}

Helga-Jane Scarwell, Richard Laganier et Marc Kaszynski, « Dossier 4 : La ville et l'enjeu du développement durable », Développement durable et territoires [En ligne], Dossier 4 | 2005, mis en ligne le 18 novembre 2005, consulté le 21 décembre 2020. URL : http://journals.openedition.org/ developpementdurable/662 ; DOI : https://doi.org/10.4000/developpementdurable.662

Ce document a été généré automatiquement le 21 décembre 2020.

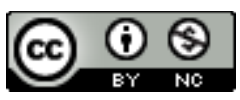

Développement Durable et Territoires est mis à disposition selon les termes de la licence Creative Commons Attribution - Pas d'Utilisation Commerciale 4.0 International. 


\title{
Dossier 4 : La ville et l'enjeu du développement durable
}

\author{
Helga-Jane Scarwell, Richard Laganier et Marc Kaszynski
}

$180 \%$ des français vivent aujourd'hui sur des territoires urbanisés, même si beaucoup habitent à la lisière de la ville et de la campagne. Paradoxalement, la ville contemporaine peut accumuler frustrations et dangers, alors que les politiques urbaines n'ont jamais été aussi attentives à améliorer la qualité du cadre et des conditions de vie et les opérations destinées à renouveler et ou à revitaliser les différents territoires de la ville aussi nombreuses. En outre, la ville s'étale sur les espaces ruraux périurbains alors que les ruraux ont des modes de vie proches de ceux des urbains. De plus, les échanges se multiplient entre les espaces urbains et ruraux en posant des questions de qualité réciproques (eau, air, sécurité alimentaire etc.) et de réception des divers sous-produits de la ville (loisirs, habitats dispersés, déchets, $\mathrm{CO} 2$ etc.).

2 La ville doit donc s'inventer un modèle de développement durable qui concilie les temporalités respectives, et les exigences environnementales, économiques et politiques. Les diverses actions publiques peuvent ainsi s'articuler afin de répondre aux interdépendances spatiales et temporelles des différents enjeux et domaines qui constituent la ville. La gestion de l'étalement urbain suppose également une réflexion sur la définition des espaces ruraux face au processus de périurbanisation. Quel nouveau statut faut-il en effet donner à ces espaces ruraux ? Quel nouvel équilibre fautil reconstituer entre les fonctions résidentielles, de productions industrielles et de services externalisés par le cœur de la "ville ", la fonction de production agricole proprement dite et la protection - consommation de l'environnement (besoins d'aménités et de biodiversité)?

3 Les contributions, théoriques et/ou empiriques, mobilisent ci-après des regards disciplinaires variés et apportent des éclairages complémentaires sur les enjeux et les stratégies à mettre en œuvre pour assurer un développement urbain durable. 